\title{
THE EFFECT OF RENTABILITY, PROFITABILITY, AND SOLVABILITY TO AUDIT DELAY
}

\author{
Riani ${ }^{1}$, Riyanto Wujarso ${ }^{2}$ \\ Beverly Hills Spekta ${ }^{1}$, STIE Jayakarta ${ }^{2}$ \\ rianirere@gmail.com ${ }^{1}$, riyanto.rw@gmail.com ${ }^{2}$
}

\begin{abstract}
This study aims to analyze the effect of rentability, profitability, and solvability on audit delay. The population in this study was 5 manufacturing companies listed on the Stock Exchange in 2015-2018. Sampling using purposive sampling. The sample in this study were 20 manufacturing companies (food and beverage subsector) listed on the Indonesia Stock Exchange (IDX). Data analysis techniques using multiple linear regression analysis. The results of this study indicate that partially rentability and profitability had a strength significant effect on audit delay, and solvability has a weak significant effect on audit delay. Simultaneously rentability, profitability, and solvability together have a significant influence on audit delay. Adjusted $R$-square value is 0,516, meaning that the magnitude of the coefficient of determination is 0.516 which states that the independent variable explains the dependent variable of $51.6 \%$. The remaining $48.4 \%$ is influenced by other variables that is not in researched.
\end{abstract}

Keywords: Rentability, Profitability, Solvability, Audit Delay

\section{PENGARUH RENTABILITAS, PROFITABILITAS, DAN SOLVABILITAS TERHADAP AUDIT DELAY}

\begin{abstract}
ABSTRAK
Penelitian ini bertujuan untuk menganalisis pengaruh rentabilitas, profitabilitas, dan solvabilitas terhadap audit delay. Populasi dalam penelitian ini adalah 5 perusahaan manufaktur yang terdaftar di Bursa Efek Indonesia (BEI) tahun 2015-2018. Pengambilan sampel dengan menggunakan purposive wampling. Sampel dalam penelitian ini adalah 20 sampel pada perusahaan manufaktur subsektor makanan dan minuman yang terdaftar di BEI. Teknik analisis data menggunakan analisis regresi linear berganda. Hasil penelitian ini menunjukkan bahwa secara parsial rentabilitas dan profitabilitas mempunyai pengaruh yang signifikan (kuat) terhadap audit delay sedangkan solvabilitas mempunyai pengaruh yang signifikan (lemah) terhadap audit delay. Secara simultan rentabilitas, profitabilitas, dan solvabilitas bersama-sama memiliki pengaruh signifikan terhadap audit delay. Nilai adjusted R-square sebesar 0.516, artinya besarnya koefisien determinasi sebesar 0.516 . Hal ini menyatakan bahwa variabel independen menjelaskan variabel dependen sebesar $51.6 \%$ sedangkan sisanya $48.4 \%$ dipengaruhi oleh faktor-faktor lainnya yang tidak diteliti.
\end{abstract}

Kata-kata Kunci: Rentabilitas, Profitabilitas, Solvabilitas, Audit Delay

Korespondensi: Riyanto Wujarso, S.E., Ak., M.M. STIE Jayakarta, Jakarta. riyanto.rw@ gmail.com 
Jurnal Manajemen dan Bisnis, Volume 2, No. 2, Januari 2021

\section{PENDAHULUAN}

Laporan keuangan merupakan proses politik dan pasar dan interaksi antara individuindividu dan kelompok-kelompok dalam prosesnya (Watts, 1977, p. 53-75). Tujuan dari laporan keuangan adalah untuk mengkomunikasikan informasi ekonomi (Stenheim, 2019). Laporan keuangan adalah alat diagnosis untuk mengevaluasi kegiatan keuangan, investasi dan operasi dan juga sebagai alat penilaian keuangan untuk pemilihan manajemen dan bisnis lain (Hasanaj and Kuqi, 2019, p. 17-27). Sementara, laporan keuangan terdiri dari laporan posisi keuangan, laporan kinerja keuangan dan penghasilan komprehensif lain, laporan perubahan ekuitas, laporan arus kas serta catatan atas laporan keuangan yang tidak dapat dipisahkan. Namun, kasus-kasus penipuan laporan keuangan dapat juga muncul ketika adanya kontrol internal yang lemah (Mohamed and Schachler, 2015, p. 46-52). Sehingga, ketepatan waktu dalam pelaporan keuangan oleh perusahaan dibutuhkan untuk memperoleh informasi laporan keuangan. Pemerintah mengatur hal tersebut melalui Peraturan Otoritas Jasa Keuangan (OJK) Nomor 29/POJK.04/2016 tentang Penyampaian Laporan Tahunan. Pasal 7 menyatakan bahwa emiten atau perusahaan publik wajib menyampaikan laporan tahunan kepada OJK paling lambat pada akhir bulan keempat setelah tahun buku berakhir. Laporan tahunan tersebut berdasarkan Standar Akuntansi Keuangan (SAK) dan diaudit oleh Akuntan
Publik yang terdaftar di Badan Pengawasan Pasar Ekuitas dan Lembaga Keuangan (BapepamL/K). Keterlambatan dalam penyampaian laporan tahunan akan berdampak negatif dari pelaku pasar ekuitas dan merupakan sinyal yang buruk bagi perusahaan. Hal ini menunjukkan bahwa informasi laporan tahunan yang dipublikasikan mengalami kenaikan atau penurunan harga saham perusahaan tersebut.

Laporan keuangan perusahaan yang disampaikan ke OJK harus disertai laporan audit oleh Akuntan Publik. Laporan audit dapat berisi informasi yang mungkin mempengaruhi estimasi dan risiko mengenai arus kas masa depan yang mungkin dicapai, informasi yang penting untuk pemegang saham (Robu and Robu, 2015, p. 562570). Laporan audit dan pengungkapan laporan audit memberikan informasi yang berguna bagi pasar dengan menemukan pengurangan signifikan dalam ketidakpastian informasi (Kaplan, Taylor, and Williams, 2020, p. 125150). Perusahaan yang mempunyai kebijakan yang bagus biasanya menghasilkan laporan audit yang berkualitas yang mana bisa meningkatkan nilai dari perusahaan tersebut (Dzikrullah, Harymawan, and Ratri, 2020). Peran auditor adalah untuk meningkatkan kepercayaan antara firma atau perusahaan dengan pemegang saham dan meningkatkan kepercayaan dalam mempresentasikan informasi melalui laporan audit (Mareque, Corrales, and Fiestras, 2015, p. 204-225). 
Jurnal Manajemen dan Bisnis, Volume 2, No. 2, Januari 2021

Pemeriksaan laporan keuangan yang dilakukan oleh auditor independen untuk menilai kewajaran penyajian laporan keuangan seharusnya maksimal adalah 120 hari setelah tahun buku berakhir sebagaimana diatur dalam Pasal 7 Peraturan OJK Nomor 29/POJK.04/2016, namun dikarenakan banyaknya transaksi yang harus diaudit dan kerumitan dari transaksi hal ini menyebabkan audit delay semakin meningkat. Audit delay diukur dengan jumlah hari yang berlalu dari akhir tahun buku sampai tanggal laporan auditor ditandatangani (Ghanem and Hegazy, 2011, p. 73-90) atau tanggal pelapor audit (Alfraih, 2016). Audit delay juga bisa dipengaruhi oleh proses politik di mana pemerintah kota beroperasi dan membuat keputusan (Cohen and Leventis, 2013, p. 40-53). Semakin pendek jangka waktu antara tanggal berakhirnya tahun tutup buku dengan tanggal publikasi laporan keuangan, semakin besar pula manfaat yang diperoleh para pengguna laporan keuangan. Sebaliknya, keterlambatan dalam mempublikasikan laporan keuangan akan mendorong ketidakpastian dalam pengambilan keputusan berdasarkan informasi yang terkandung dalam laporan keuangan. .

Meskipun penelitian telah banyak dilakukan mengenai audit delay pada perusahaan yang terdaftar di BEI namun hasil penelitian tersebut beragam, hal ini disebabkan karena perbedaan sifat variabel independen dan variabel dependen yang diteliti, perbedaan periode pengamatan serta perbedaan dalam metodologi statistik yang digunakan dalam penelitian .

Mengingat pentingnya ketepatan waktu pelaporan keuangan bagi pembuat keputusan, dimana audit delay menjadi salah satu faktor yang memengaruhi terlambatnya pelaporan keuangan, menjadikan audit delay serta faktorfaktor yang memengaruhinya dapat menjadi salah satu objek yang dapat diteliti.

Penelitian ini memberikan kontribusi berupa kepastian hasil untuk menentukan apakah variabel-variabel yang diteliti memang memiliki pengaruh atau tidak. Karena penelitian terdahulu masih memiliki pertentangan hasil penelitian. Terdapat variabel-variabel yang berpengaruh dan tidak berpengaruh terhadap audit delay.

Peneliti tertarik untuk mengetahui audit delay yang terjadi dengan variabel independen berupa rentabilitas, profitabilitas, dan solvabilitas serta objek penelitian yang difokuskan pada perusahaan manufaktur subsektor makanan dan minuman yang terdapat di dalam BEI. Peneliti merumuskan penelitian ini dengan judul "Pengaruh Rentabilitas, Profitabilitas, dan Solvabilitas terhadap Audit Delay (Studi Empiris pada Perusahaan Manufaktur Subsektor Makanan dan Minuman yang Terdaftar di BEI Periode 2015 - 2018)."

\section{KAJIAN LITERATUR}

Rentabilitias adalah kemampuan suatu perusahaan untuk menghasilkan laba selama periode tertentu dan umumnya dirumuskan 
Jurnal Manajemen dan Bisnis, Volume 2, No. 2, Januari 2021

sebagai L/M. L adalah jumlah laba yang diperoleh dalam periode tertentu dan $\mathrm{M}$ adalah ekuitas atau aset yang digunakan untuk menghasilkan laba tersebut. Menurut Kasmir (2016), rasio rentabilitas memiliki tujuan dan manfaat, tidak hanya bagi pihak pemilik usaha atau manajemen saja, tetapi juga bagi pihak luar bank, terutama pihak-pihak yang memiliki hubungan atau kepentingan dengan bank. Sedangkan, menurut Munawir (2019), ada dua jenis rasio rentabilitas yaitu, rentabilitas ekonomi dan rentabilitas ekuitas sendiri. Rentabilitas ekonomi menawarkan keamanan yang lebih besar untuk menyimpulkan tentang indikator ekonomi (Castro, Silva, Leite, and Oliveira, 2007).

Profitabilitas dan persaingan yang kuat dalam industri manufaktur mungkin dipengaruhi oleh biaya tenaga kerja (Pervan, and Curak, 2019, p. 968-981). Dengan perkembangan yang baik, membuka peluang baru untuk mendorong efisiensi dan profitabilitas melalui berbagai jenis investasi dan skala serta cakupan ekonomi sehingga menghasilkan umpan balik yang positif (Bottazzi, Secchi, and Tamagni, 2008, p. 711751). Profitabilitas dihitung dari pengembalian aset (Return on Assets /ROA), pengembalian modal penyerta (Return on Equity/ROE), dan pengembalian penjualan (Return on Sales/ROS) (Ziarko, 2015, p. 152-161). Hal yang sama juga dinyatakan oleh Rahmah dan Komariah (2016) bahwa rasio profitabilitas mengukur kemampuan perusahaan untuk menghasilkan keuntungan pada tingkat penjualan, aset, dan ekuitas saham tertentu. Pengukuran rasio profitabilitas memungkinkan analisis untuk mengevaluasi keuntungan atau laba perusahaan pada penjualan, aset, dan investasi pemilik (Ichsani dan Suhardi, 2015, p. 896-902).

Solvabilitas mempengaruhi pemilihan struktur modal yang mana hubungannya dengan kapasitas untuk memenuhi hutang jangka panjang (Yeo, 2016., p. 235-241). Solvabilitas dipengaruhi oleh kondisi dan situasi bisnis, seperti misalnya di era pandemi Covid-19 yang mungkin meningkatkan kebangkrutan korporasikorporasi (Mirza, Rahat, Naqvi, and Rizvi, 2020). Sebagai contoh juga, di Kroasia ada penelitian yang penting pada kemungkinan dari penggunaan model yang sudah ada untuk menentukan kemampuan perusahaan domestik untuk menjaga solvabilitas (Grdić, Nižić, and Mamula, 2017, p. 1693-1704). Salah satu ide untuk meningkatkan model penetapan harga aset bisnis adalah memasukkan likuiditas atau solvabilitas perusahaan ke dalam analisis (Zalewska and Nehrebecka, 2020).

Berdasarkan penelitian dari Masodah dan Mustikaningrum (2009), pengaruh rentabilitas terhadap audit delay mendapatkan hasil berpengaruh negatif. Sementara, menurut Kartika (2011, p. 152-171), profitabilitas tidak berpengaruh terhadap audit delay yang berarti bahwa meskipun perusahaan semakin besar profitnya, namun tidak mengurangi waktu penyelesaian laporan keuangan auditan. 
Jurnal Manajemen dan Bisnis, Volume 2, No. 2, Januari 2021

Berdasarkan penelitian Utami (2006), faktor yang berpengaruh signifikan terhadap audit delay adalah umur perusahaan dan profitabilitas. Sedangkan, solvabilitas berdasarkan Kartika (2011) mempunyai pengaruh positif terhadap audit delay, sementara Utami (2006) melihat solvabilitas tidak berpengaruh terhadap audit delay.

\section{METODE}

Jenis penelitian yang digunakan dalam penelitian ini adalah penelitian deskriptif kuantitatif. Menurut Sofar Silaen (2018), metode penelitian kuantitatif dapat diartikan sebagai metode penelitian yang berlandaskan pada filsafat positivisme, digunakan untuk meneliti pada populasi atau sampel tertentu, pengumpulan data menggunakan instrumen penelitian, analisis data bersifat kuantitatif/statistik, dengan tujuan untuk menguji hipotesis yang telah ditetapkan. Sementara, penelitian deskriptif adalah sebuah metode yang bertujuan untuk melukiskan atau menggambarkan keadaan di lapangan secara sistematis dengan fakta-fakta dan interpretasi yang tepat, serta bukan hanya sekadar mencari kebenaran mutlak akan tetapi pada hakekatnya mencari pemahaman observasi.

Pengumpulan data pada penelitian ini adalah dengan menggunakan metode pengumpulan data sekunder yang bersumber dari laporan keuangan tahunan perusahaan selama periode penelitian yang diakses melalui situs www.idx.co.id. Data yang diperoleh diolah dengan menggunakan SPSS versi 24. Sementara itu populasi yang dijadikan obyek adalah perusahaan-perusahaan yang termasuk dalam perusahaan manufaktur subsektor makanan dan minuman yang yang terdaftar di BEI selama periode 2015 s.d. 2018. Sampel dalam penelitian ini sebanyak 5 perusahaan sehingga jumlah sampel keseluruhan $=5 \times 4=20$ laporan. Teknik pengambilan sampel yang digunakan dalam pengambilan sampel yaitu teknik purposive sampling. Tabel 3.1 merupakan perusahaan yang dijadikan sampel.

Tabel 3.1 Perusahaan sebagai Sampel

\begin{tabular}{|c|l|c|}
\hline No & \multicolumn{1}{|c|}{ Nama Perusahaan } & Kode \\
\hline$(1)$ & \multicolumn{1}{|c}{$(2)$} & $(3)$ \\
\hline 1 & PT Wilmar Cahaya Indonesia Tbk & CEKA \\
\hline 2 & PT Delta Djakarta Tbk & DLTA \\
\hline 3 & PT Indofood Cbp Sukses Makmur Tbk & ICBP \\
\hline 4 & PT Indofood Sukses Makmur Tbk & INDF \\
\hline 5 & PT Mayora Indah Tbk & MYOR \\
\hline
\end{tabular}

Teknik analisis data menggunakan rumusrumus pengukuran rasio rentabilitas, profitabilitas, dan solvabilitas serta audit delay. Selain itu, dilakukan juga analisis statistik deskriptif, analisis asumsi klasik dengan uji normalitas, uji multikolinearitas, uji autokorelasi, uji heteroskedastisitas, kemudian analisis regresi linear berganda, analisis koefisien korelasi dengan koefisien korelasi parsial dan koefisien korelasi berganda, analisis uji hipotesis dengan uji parsial (Uji t), uji statistik F (Uji F), dan koefisien determinasi. 
Jurnal Manajemen dan Bisnis, Volume 2, No. 2, Januari 2021

\section{HASIL DAN PEMBAHASAN}

\subsection{Rentabilitas}

Rumus yang digunakan untuk mengukur rentabilitas adalah laba setelah pajak dibagi modal dikalikan 100 persen. Hasil perhitungan menunjukkan bahwa nilai rentabilitas tertinggi sebesar 27,93 pada CEKA tahun 2016 dan terendah 10,28 juga pada CEKA tahun 2018.

\subsection{Profitabilitas}

Rumus yang digunakan untuk mengukur profitabilitas (ROA) adalah laba setelah pajak dibagi total asset dikalikan 100 persen. Hasil perhitungan menunjukkan bahwa nilai profitabilitas tertinggi sebesar 22,82 pada DLTA tahun 2018 dan terendah sebesar 5,30 pada INDF tahun 2015.

\subsection{Solvabilitas}

Rumus yang digunakan untuk mengukur profitabilitas (Debt to Equity Ratio/DER) adalah total utang dibagi total ekuitas dikalikan 100 persen. Hasil perhitungan menunjukkan bahwa nilai solvabilitas tertinggi sebesar 132,20 pada CEKA tahun 2015 dan terendah sebesar 14,14 pada DLTA tahun 2017.

\subsection{Audit Delay}

Audit delay diukur dari tanggal penutupan tahun buku hingga tanggal diterbitkannya laporan audit (Audit Delay = Tanggal
Laporan Audit - Tanggal Laporan Keuangan). Dari hasil perhitungan menunjukkan bahwa audit delay yang paling lama adalah 90 hari yaitu pada DLTA tahun 2015 dan paling pendek 67 hari pada CEKA tahun 2017.

\subsection{Analisis Statistik Deskriptif}

Hasil dari pengujian statistik deskriptif dari variabel penelitian rentabilitas, profitabilitas, solvabilitas, dan audit delay tergambar dalam tabel 4.1 berikut:

\section{Tabel 4.1 Analisis Deskriptif}

\begin{tabular}{lrrrrr}
\hline & \multicolumn{2}{c}{ Rentabilitas } & Profitabilitas & Solvabilitas & Audit \\
& & 20 & 20 & 20 \\
\hline $\mathrm{N}$ & Valid & 0 & 0 & 0 & 0 \\
\cline { 2 - 6 } \multicolumn{1}{c}{ Missing } & 18.89285 & 12.00735 & 69.13210 & 79.80 \\
\hline Mean & 5.893624 & 5.537450 & 37.650706 & 5.493 \\
Std. Deviation & 34.735 & 30.663 & 1417.576 & 30.168 \\
Variance & 10.278 & 5.300 & 17.140 & 67 \\
Minimum & 27.933 & 22.822 & 132.199 & 90 \\
Maximum & & & & \\
\hline
\end{tabular}

1. Variabel rentabilitas memiliki rata-rata sebesar 18.89285, standar deviasi 5.893624, nilai minimum sebesar 10.278, dan nilai maximum sebesar 27.933 .

2. Variabel profitabilitas memilki rata-rata sebesar 12.00735, standar deviasi 5.537450, nilai minimum sebesar 5.300, dan nilai maximum sebesar 22.822 .

3. Variabel solvabilitas memilki rata-rata sebesar 69.13210, standar deviasi 37.650706 nilai minimum sebesar 17.140, dan nilai maximum sebesar 132.199. 
Jurnal Manajemen dan Bisnis, Volume 2, No. 2, Januari 2021

4. Variabel audit delay memiliki rata-rata sebesar 79.80, standar deviasi 5.493, nilai minimum sebesar 67 , dan nilai maximum sebesar 90 .

\subsection{Analisis Asumsi Klasik}

Asumsi klasik mencakup uji normalitas, uji multikolinearitas, uji heteroskedastisitas, dan uji autokorelasi.

\section{Uji Normalitas}

Uji Normalitas bertujuan untuk menentukan apakah suatu data telah terdistribusi dengan normal atau tidak. Kriteria uji normalitas yaitu data tidak terdistribusi normal jika nilai signifikansi $<0,05$ dan data terdistribusi normal jika nilai signifikansi > 0,05. Hal ini dapat dilihat dari hasil uji normalitas pada grafik histogram dan grafik probability plot. Pada gambar histogram terlihat nilai residu (error) menunjukkan distribusi normal, yakni gambar berbentuk lonceng.

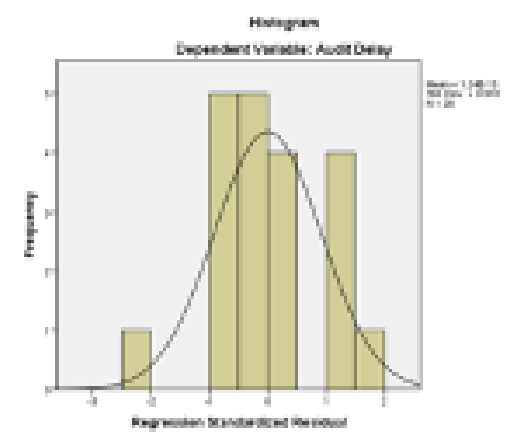

Gambar 4.1 Histogram

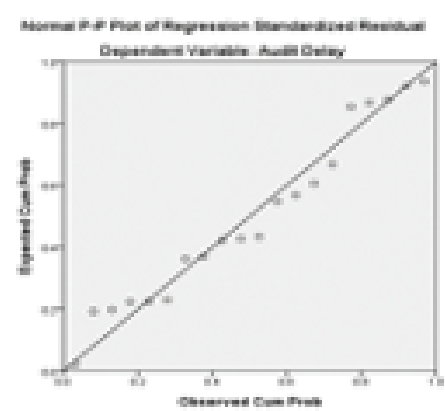

Gambar 4.2 Normal Probability Plot

Pada gambar normal probability plot terlihat sebaran residu berupa dot sebanyak jumlah sampel $=20$ masih berada di sekitar atau tidak jauh dari garis lurus. Hal ini menunjukkan distribusi normal.

2. Uji Multikolinearitas

Hasil uji multikolinearitas memperlihatkan bahwa penelitian ini bebas dari adanya multikolinearitas. Hal ini dapat dilihat dengan membandingkan dengan nilai tolerance dan VIF. Masing-masing variabel bebas yang digunakan dalam penelitian ini memiliki nilai tolerance mendekati nilai 1 atau 0.916 yaitu untuk rentabilitas nilai tolerance 0.916 dan solvabilitas nilai tolerance 0.916 . Jika dilihat dari VIF-nya, bahwa masing-masing variabel bebas sekitar nilai 1 yaitu untuk VIF rentabilitas 1.092 dan VIF solvabilitas 1.092. Dapat disimpulkan bahwa tidak terjadi multikolinieritas pada variabel bebas. 
Jurnal Manajemen dan Bisnis, Volume 2, No. 2, Januari 2021

Tabel 4.2 Hasil Uji Multikolinearitas

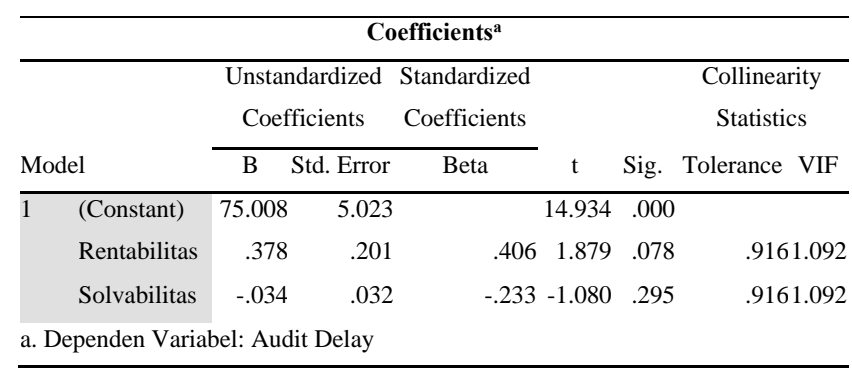

3. Uji Heteroskedastisitas

Berdasarkan output Scatterplot, terlihat bahwa titik-titik menyebar dan tidak membentuk pola tertentu yang jelas. Sehingga dapat disimpulkan bahwa tidak terjadi masalah heteroskedastisitas.

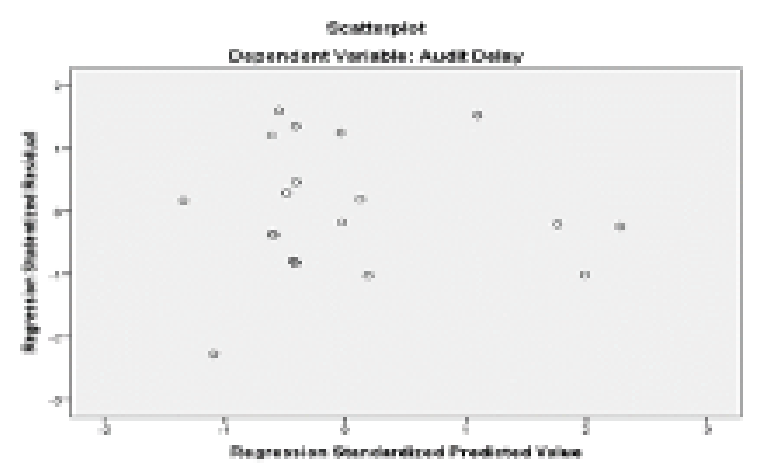

Gambar 4.3 Hasil Uji

\section{Heteroskedastisitas dengan}

\section{Scatterplot}

4. Uji Autokorelasi

Uji autokorelasi digunakan untuk mengetahui ada atau tidaknya penyimpangan asumsi klasik autokorelasi yaitu korelasi yang terjadi antara residual pada satu pengamatan dengan pengamatan lain pada model regresi. Syarat yang harus terpenuhi adalah tidak adanya autokorelasi dalam model regresi. Hasil regresi dengan nilai signifikan 0.05 dengan jumlah variabel independen $(\mathrm{k}=3)$ dan banyaknya data $(n=20)$. Dengan demikian berdasarkan tabel Durbin Watson dengan $\alpha=0,05$ maka nilai $d_{L}$ $=0.9976$, dan $\mathrm{dU}=1,6763$. Hasil dari uji autokorelasi sebagai berikut.

\section{Tabel 4.3 Hasil Uji Autokorelasi dengan Durbin-Watson}

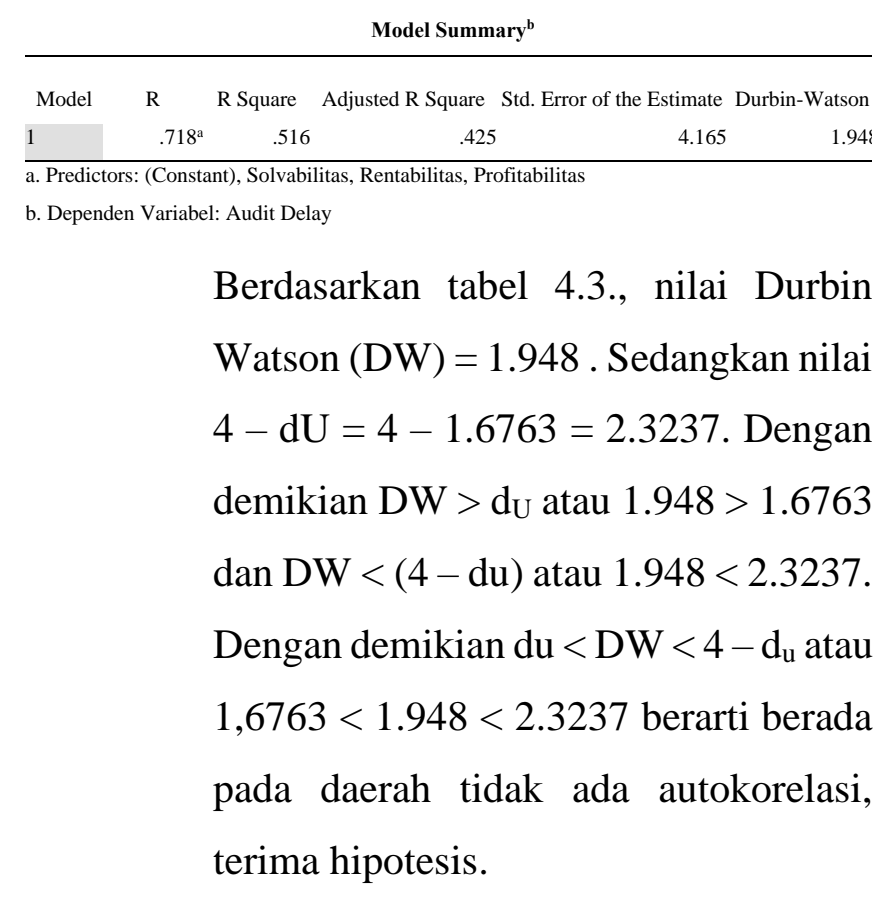

5. Analisis Regresi Linear Berganda Analisis Regresi Linear Berganda digunakan untuk mengetahui besarnya pengaruh variabel rentabilitas $\left(\mathrm{X}_{1}\right)$, profitabilitas $\left(\mathrm{X}_{2}\right)$ dan solvabilitas $\left(\mathrm{X}_{3}\right)$ secara parsial maupun secara bersamasama terhadap audit delay (Y). 
Jurnal Manajemen dan Bisnis, Volume 2, No. 2, Januari 2021

Tabel 4.4 Hasil Analisis Regresi Linear

\section{Berganda}

\begin{tabular}{|c|c|c|c|c|c|c|}
\hline \multicolumn{7}{|c|}{ Coefficients ${ }^{\mathrm{a}}$} \\
\hline & \multirow{3}{*}{ Model } & Unstand & ardized & \multirow{2}{*}{$\begin{array}{l}\text { Standardized } \\
\text { Coefficients }\end{array}$} & \multirow{3}{*}{$\mathrm{T}$} & \multirow{3}{*}{ Sig. } \\
\hline & & Coeffic & cients & & & \\
\hline & & $\mathrm{B}$ & Std. Error & Beta & & \\
\hline \multirow[t]{4}{*}{$\overline{1}$} & (Constant) & 62.794 & 6.044 & & 10.389 & .000 \\
\hline & Rentabilitas & -1.344 & .632 & -1.442 & -2.126 & .049 \\
\hline & Profitabilitas & 2.602 & .920 & 2.623 & 2.827 & .012 \\
\hline & Solvabilitas & .161 & .074 & 1.105 & 2.180 & .045 \\
\hline
\end{tabular}

Model persamaan regresi yang dapat dituliskan dari hasil tersebut dalam bentuk persamaan regresi adalah sebagai berikut: $Y=a+b_{1} X_{1}+b_{2} X_{2}+$ $\mathrm{b}_{3} \mathrm{X}^{3}$.

Berdasarkan tabel 4.4., nilai a $=62.794$; nilai $b_{1}=-1.344$; nilai $b_{2}=2.602$; dan nilai $\mathrm{b}_{3}=0.161$; dengan demikian rumus regresi linear berganda sebagai berikut: $\mathrm{Y}=62.794-1.344 \mathrm{X}_{1}+2.602$ $\mathrm{X}_{2}+0.161 \mathrm{X}_{3}$.

\section{Keterangan:}

a. Nilai konstanta a $=62.794$ memberikan arti bahwa jika variabel bebas diabaikan atau dengan kata lain jika tidak ada variasi pada rentabilitas, profitabilitas, dan solvabilitas, maka audit delay akan bernilai 62.794 satuan.

b. Nilai koefisien b1 $=-1.344$ hal ini berarti bahwa setiap peningkatan satu satuan pada rentabilitas dengan asumsi variabel profitabilitas dan solvabilitas konstan, maka audit delay akan mengalami penurunan sebesar 1.344 satuan dan bergerak ke arah yang berlawanan (arah negatif).

c. Nilai koefisien $b_{2}=2.602$ hal ini berarti bahwa setiap peningkatan satu satuan pada profitabilitas dengan asumsi variabel rentabilitas dan solvabilitas konstan, maka audit delay akan mengalami peningkatan sebesar 2.602 satuan dan bergerak ke arah yang sama (arah positif).

d. Nilai koefisien $b_{3}=0.161$ hal ini berarti bahwa setiap peningkatan satu satuan pada solvabilitas dengan asumsi variabel rentabilitas dan profitabilitas konstan, maka audit delay akan mengalami peningkatan sebesar 0.161 satuan dan bergerak ke arah yang sama (arah positif).

\subsection{Analisis Koefisien Korelasi}

Koefisien korelasi digunakan untuk melihat pengaruh variabel independen dengan variabel dependen, maka perlu dilakukan analisis korelasi antarvariabel penelitian secara individu (parsial) yang hasilnya dapat dilihat pada tabel 4.5. di bawah ini: 
Jurnal Manajemen dan Bisnis, Volume 2, No. 2, Januari 2021

Tabel 4.5 Hasil Analisis Koefisien Korelasi

\begin{tabular}{|c|c|c|c|c|c|}
\hline \multicolumn{6}{|c|}{$\begin{array}{l}\text { Analisis } \\
\text { Correlations }\end{array}$} \\
\hline & & Audit Delay & Rentabilitas & Profitabilitas & Solvabilitas \\
\hline \multirow[t]{4}{*}{ Pearson Correlation } & Audit Delay & 1.000 & .473 & .605 & $\overline{-.351}$ \\
\hline & Rentabilitas & .473 & 1.000 & .852 & -.290 \\
\hline & Profitabilitas & .605 & .852 & 1.000 & -.715 \\
\hline & Solvabilitas & -.351 & -.290 & -.715 & 1.000 \\
\hline \multirow[t]{4}{*}{ Sig. (1-tailed) } & Audit Delay & . & .018 & .002 & .065 \\
\hline & Rentabilitas & .018 & & .000 & .107 \\
\hline & Profitabilitas & .002 & .000 & 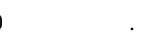 & .000 \\
\hline & Solvabilitas & .065 & .107 & .000 & \\
\hline \multirow[t]{4}{*}{$\mathrm{N}$} & Audit Delay & 20 & 20 & 20 & 20 \\
\hline & Rentabilitas & 20 & 20 & 20 & 20 \\
\hline & Profitabilitas & 20 & 20 & 20 & 20 \\
\hline & Solvabilitas & 20 & 20 & 20 & 20 \\
\hline
\end{tabular}

Berdasarkan tabel 4.5, nilai korelasi Pearson dari masing-masing variable sebagai berikut:

1. Nilai koefisien korelasi (r) pada variabel rentabilitas sebesar 0.473 . Nilai 0.473 berada dalam rentang $0.40 \leq \mathrm{r}<0.60$, berarti hubungan antara rentabilitas dengan audit delay dikategorikan cukup erat.

2. Nilai signifikansi $(\alpha)$ pada variabel rentabilitas sebesar $0.018<0.05$, berarti terdapat hubungan rentabilitas dengan audit delay.

3. Nilai koefisien korelasi (r) pada variabel profitabilitas sebesar 0.605 . Nilai 0.605 berada dalam rentang $0.60 \leq \mathrm{r}<0.80$, berarti hubungan antara profitabilitas dengan audit delay dikategorikan erat.

4. Nilai signifikansi $(\alpha)$ pada variabel profitabilitas sebesar $0.002<0.05$, berarti terdapat hubungan profitabilitas dengan audit delay.
5. Nilai koefisien korelasi (r) pada variabel solvabilitas sebesar -0.351 . Nilai -0.351 berada dalam rentang $-0.40 \leq \mathrm{r}<-0.20$, berarti hubungan antara solvabilitas dengan audit delay dikategorikan lemah.

\subsection{Analisis Uji Hipotesis}

1. Uji Parsial (Uji t)

Hasil Uji t tergambar pada tabel 4.6 di bawah ini:

\section{Tabel 4.6 Hasil Uji Parsial dengan uji t}

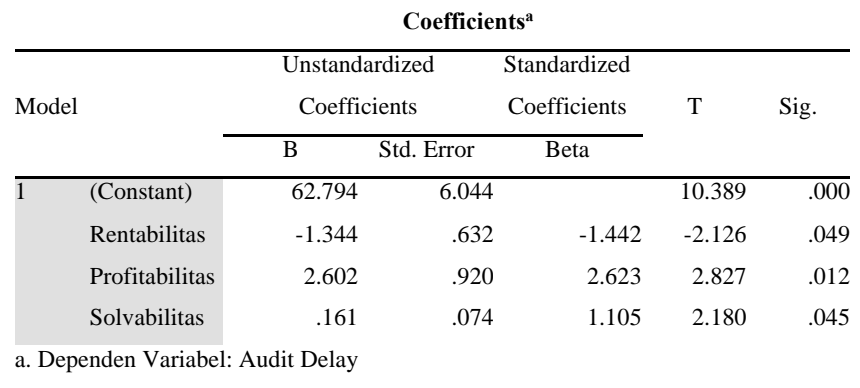

Berdasarkan tabel 4.6. dapat dikatakan bahwa terdapat pengaruh variabel rentabilitas terhadap audit delay. Hal ini dibuktikan dengan nilai t hitung $=-2.126<-2.10092$ dan nilai probabilitas sebesar $0.049<0.05$.

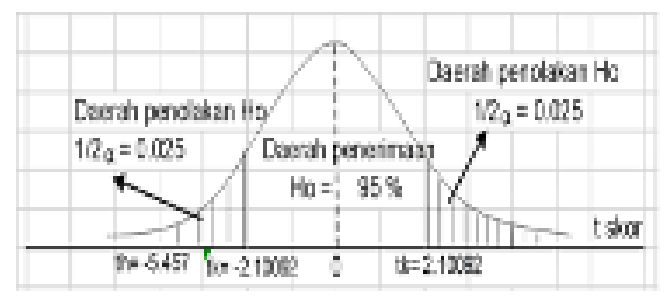

\section{Gambar 4.4 Kurva Uji t Rentabilitas}

Masih berdasarkan tabel 4.6. dapat dikatakan bahwa terdapat pengaruh variabel profitabilitas terhadap audit delay. Hal ini 
Jurnal Manajemen dan Bisnis, Volume 2, No. 2, Januari 2021

dibuktikan dengan nilai $\mathrm{t}$ hitung $=2.827>$

2.10092 dan nilai probabilitas sebesar 0.012 $<0.05$.

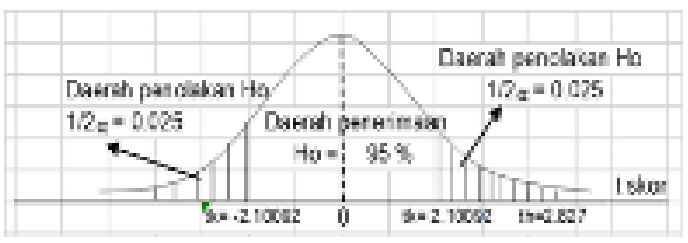

\section{Gambar 4.5 Kurva Uji t Profitabilitas}

Kemudian pengaruh solvabilitas terhadap audit delay dapat dianalisis berdasarkan tabel 4.6. Hasilnya adalah nilai t hitung $=2.180>$ 2.10092 dan nilai probabilitas sebesar 0.045 $<0.05$ yang berarti bahwa pengaruh variabel solvabilitas terhadap audit delay.

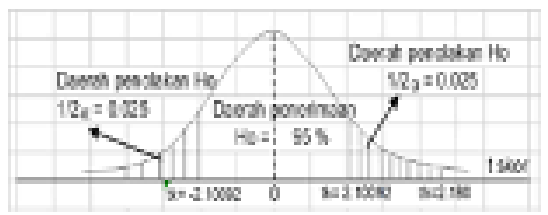

\section{Gambar 4.6 Kurva Uji t Solvabilitas}

2. Uji Simultan (Uji F)

Tabel 4.7 Hasil Uji Simultan (Uji F)

\begin{tabular}{|c|c|c|c|c|c|c|}
\hline \multicolumn{7}{|c|}{ ANOVA $^{a}$} \\
\hline & Model & Sum of Squares & df & Mean Square & $\mathrm{F}$ & Sig. \\
\hline \multirow[t]{3}{*}{1} & Regression & 295.681 & 3 & 98.560 & 5.682 & $.008^{b}$ \\
\hline & Residual & 277.519 & 16 & 17.345 & & \\
\hline & Total & 573.200 & 19 & & & \\
\hline
\end{tabular}

b. Predictors: (Constant), Solvabilitas, Rentabilitas, Profitabilitas

Berdasarkan tabel 4.7 nilai $\mathrm{F}$ hitung $=5.682$ $>3.24$ dan nilai probabilitas $0.008<0,05$ yang berarti bahwa terdapat pengaruh antara rentabilitas, profitabilitas, dan solvabilitas secara simultan terhadap audit delay perusahaan.

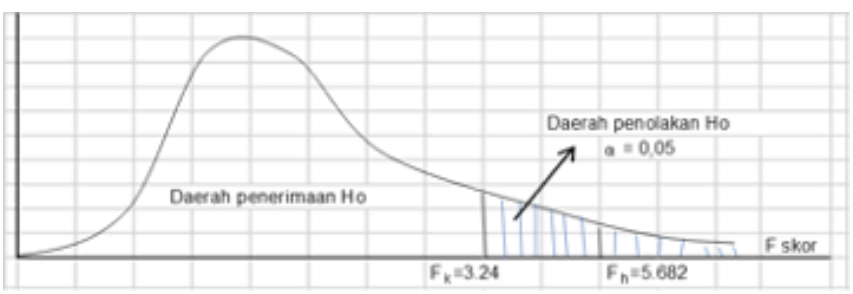

Gambar 4.7 Kurva Uji Simultan Uji F

\subsection{Koefisien Determinasi}

Dalam penelitian ini menggunakan lebih dari dua variabel independen. Nilai koefisien determinasi adalah nilai adjusted $\mathrm{R}$ Square. Tabel 4.8 menghasilkan nilai koefisien determinasi atau adjusted $\mathrm{R}$ Square $=0.425$. Hal ini menunjukkan bahwa besarnya konstribusi rentabilitas, profitabilitas, dan solvabilitas terhadap audit delay adalah sebesar $42.5 \%$ sedangkan sisanya $57.5 \%$ dipengaruhi oleh faktor-faktor lainnya yang tidak diteliti.

\section{Tabel 4.8 Hasil Analisis Koefisien Determinasi}

\begin{tabular}{lcccc}
\multicolumn{4}{c}{ Model Summary $^{\mathbf{b}}$} \\
\hline Model & $\mathrm{R}$ & R Square & Adjusted R Square & Std. Error of the Estimate \\
\hline 1 & $.718^{\mathrm{a}}$ & .516 & .425 & 4.165 \\
\hline a. Predictors: (Constant), Solvabilitas, Rentabilitas, Profitabilitas \\
b. Dependen Variabel: Audit Delay
\end{tabular}

\section{KESIMPULAN}

Dari hasil pengujian dan analisis dapat disimpulkan bahwa terdapat pengaruh rentabilitas, profitabilitas, dan solvabilitas terhadap audit delay pada perusahaan manufaktur subsektor makanan dan minuman yang terdaftar 
Jurnal Manajemen dan Bisnis, Volume 2, No. 2, Januari 2021

di BEI periode observasi tahun 2015 sampai tahun 2018, baik secara parsial maupun simultan.

Besarnya konstribusi rentabilitas, profitabilitas dan solvabilitas terhadap audit delay adalah sebesar $42,5 \%$ sedangkan sisanya $57,5 \%$ dipengaruhi oleh faktor-faktor lainnya yang tidak diteliti.

Disarankan agar manajemen selalu memperhatikan faktor-faktor yang mempengaruhi audit delay dan memberikan datadata yang diperlukan auditor dalam jangka waktu segera untuk membantu kinerja auditor dalam mengaudit laporan keuangan perusahaan, yang pada akhirnya laporan keuangan teraudit dapat disajikan tepat waktu.

\section{DAFTAR PUSTAKA}

\section{Buku}

Dermawan, Deni. (2013). Metode Penelitian Kuantitatif. Bandung: Remaja Rosdakarya.

Kasmir. (2016). Analisis Laporan Keuangan, Jakarta: Rajawali.

M. N. Rahmah and E. Komariah. (2016). Analisis Laporan Keuangan dalam Menilai Kinerja Keuangan Industri Semen yang Terdaftar di BEI, dalam Analisis Laporan Keuangan. Yogyakarta: UPP STIM YKPN.

Munawir. (2019). Analisa Laporan Keuangan, Yogyakarta: Liberty.

Priyatno, D. (2016). Belajar Alat Analisis Data dan Cara Pengolahannya dengan SPSS. Yogyakarta: Penerbit Gava Media.

S. Silaen. (2018). Metodologi Penelitian Sosial Untuk Penulisan Skripsi dan Tesis. Jakarta.

Wahyuddin. (2015). Pengolahan Data dengan Program Statistical Package For The Sosial Sciences
(SPSS) Versi 21. Makassar: Lembaga Perpustakaan dan Penerbitan Universitas Muhammadiyah Makassar.

Widjaya. (2019). Aplikasi Analisis Multivariete dengan Program IBM SPSS Versi 23. Yogyakarta: Badan Penerbit Universitas Diponegoro.

\section{Artikel dari website tanpa nama penulis}

OJK. 2016. Laporan Tahunan Emiten atau Perusahaan Publik. (Diambil Kembali dari Peraturan Otoritas Jasa Keuangan Nomor 29 /Pojk.04/2016 Pasal 7). Https://www.Ojk.Go.Id/Id/Kanal/PasarModal/Regulasi/Peraturan-Ojk/Pages/Pojk-LaporanTahunan-Emiten-Perusahaan-Publik.Aspx.

Peng-Spt-00007/Bei.Pp2/07-2018. Pengumuman Penyampaian Laporan Keuangan Tahunan yang Berakhir per 31 Desember 2017. (Diambil Kembali dari Indonesia Stock Exchange www.Idx.Co.Id

Peng-Spt-00009/Bei.Pp2/07-2017. Pengumuman Penyampaian Laporan Keuangan Tahunan yang Berakhir per 31 Desember 2016. (Diambil kembali dari Indonesia Stock Exchange). www.Idx.Co.Id

\section{Jurnal cetak}

A. D. Dzikrullah, I. Harymawan and M. C. Ratri. (2020). Internal audit functions and audit outcomes: Evidence from Indonesia. Cogent Business \& Management, Vol. 7 (1).

A. Kartika. (2011). Faktor-Faktor yang Mempengaruhi Audit Delay pada Perusahaan Manufaktur yang terdaftar di BEI. Dinamika Keuangan dan Perbankan. Universitas Stikubank, Vol 3 (2), 152-171.

A. Rutkowska-Ziarko. (2015). The Influence of Profitability Ratios and Company Size on Profitability and Investment Risk in the Capital Market. Folia Oeconomica Stetinensia, Vol. 15 (1), 152-161.

Eksandy, A. (2017). Pengaruh Ukuran Perushaan, Solvabilitas, Profitabilitas dan Komite Audit terhadap Audit Delay. Competitive Jurnal Akuntansi dan Keuangan, Vol.1 No.2.

Fiatmoko, Arizal Latif dan Indah Anisykurlillah. (2015). Faktor-Faktor yang Berpengaruh terhadap Audit Delay pada Perusahaan Perbankan. 


\section{Jurnal Manajemen dan Bisnis, Volume 2, No. 2, Januari 2021}

Accounting Analysis Journal Universitas Semarang. ISSN: 2252-6765.

G. Bottazzi, A. Secchi and F. Tamagni. (2008). Productivity, profitability and financial performance. Industrial and Corporate Change, Vol. 17 (4), 711751.

H. Yeo. (2016). Solvency and Liquidity in Shipping Companies. The Asian Journal of Shipping and Logistics, Vol. 32 (4), 235-241.

Iskandar, M. J., \& Trisnawati, E. (2010). FaktorFaktor yang Mempengaruhi Audit Report Lag pada Perusahaan yang Terdaftar di Bursa Efek Indonesia. Jurnal Bisnis Dan Akuntansi, Vol. 12, No. 3, 175 186.

J. Zalewska and N. Nehrebecka. (2020). Liquidity and solvency of a company and the rate of return - an analysis of the Warsaw Stock Exchange. Central European Economic Journal, Vol. 6 (53).

K. M. Baksaas and T. Stenheim. (2019). Proposal for improved financial statements under IFRS. Cogent Business \& Management, Vol 6 (1).

M. A. Robu and I. B. Robu. (2015). The Influence of the Audit Report on the Relevance of Accounting Information Reported by Listed Romanian Companies. Procedia Economics and Finance, Vol. 20, 562-570.

Masodah dan F. Mustikaningrum. (2009). Pengaruh Rentabilitas, Size, dan Struktur Modal terhadap Keterlambatan Publikasi Laporan Keuangan Perusahaan Go Public Sektor Aneka Industri dan Sektor Industri Dasar dan Kimia. Proceeding PESAT Psikologi, Ekonomi, Sastra, Arsitektur \& Sipil), Vol. 3.

Mustikawati, I. (2015). Pengaruh Ukuran Perusahaan, Umur Perusahaan, Profitabilitas, Solvabilitas, Ukuran Kap, dan Opini Auditor terhadap Audit Delay. Jurnal Nominal, Volume IV, Nomor 2.

M. M. Alfraih. (2016). Corporate governance mechanisms and audit delay in a joint audit regulation. Journal of Financial Regulation and Compliance, Vol. 24 (3).

M. Mareque, F. Lopez-Corrales and G. Fiestras. (2015). Do auditors make mistakes when they write audit reports? An empirical study applied to Spanish non-listed firms. Economic ResearchEkonomska Istraživanja, 28 (1), 204-225.

M. Pervan, I. Pervan and M. Curak. (2019). Determinants of firm profitability in the Croatian manufacturing industry: evidence from dynamic panel analysis. Economic Research-Ekonomska Istraživanja, 32 (1), 968-981.

N. Mirza, B. Rahat, B. Naqvi and S. K. A. Rizvi. (2020). Impact of Covid-19 on corporate solvency and possible policy responses in the EU, "QRev Econ Finance.

N. Mohamed and M. Handley-Schachler. (2015). Roots of Responsibilities to Financial Statement Fraud Control. Procedia Economics and Finance, Vol. 28, 46-52.

P. Hasanaj and B. Kuqi. (2019). Analysis of Financial Statements. Humanities and Social Science Research, 2 (2), 17-27.

Puspitasari, Elen dan A. N. Sari. (2012). Pengaruh Karakteristik Perusahaan terhadap Lamanya Waktu Penyelesaian Audit (Audit Delay) pada Perusahaan Manufaktur yang Terdaftar di Bursa Efek Indonesia. Jurnal Akuntansi dan Auditing Volume 9, No.1.

Putra, I.W. (2014). Pengaruh Financial Distress, Rentabilitas, Pertumbuhan Perusahaan dan Opini Audit pada Pergantian Auditor. Universitas Udayana, Bali, Indonesia: E-Jurnal Akuntasi Universitas Udayana 8.2.

Putra, P.G. dan I. M. Putra. (2014). Ukuran Perusahaan sebagai Pemoderasi Pengaruh Opini Auditor, Profitabilitas, dan Debt to Equity Ratio terhadap Audit Delay. Denpasar: E-Jurnal Akuntansi Universitas Udayana 5.2.

R. L. Watts. (1977). Corporate Financial Statements, A Product of the Market and Political Processes. Australian Journal of Management, Vol. 2(1), 53-75.

R. R. de Castro, M. L. Da Silva, H. G. Leite and M. L. R. de Oliveira. (2007). Economic rentability and risk on charcoal production. ResearchGate, 13 (4).

Saemargani, F.I. (2015). Analisis Determinan Audit Delay Kajian Empiris di Bursa Efek Jakarta. Jurnal nominal, Volume IV Nomor 2. 
Jurnal Manajemen dan Bisnis, Volume 2, No. 2, Januari 2021

S. Cohen and S. Leventis. (2013). Effects of municipal, auditing and political factors on audit delay. Accounting Forum, Vol. 37 (1), 40-53.

S. E. Kaplan, G. K. Taylor and D. D. Williams. (2020). The Effects of the Type and Content of Audit Reports for Financially Stressed Initial Public Offerings on Information Uncertainty. AUDITING: A Journal of Practice \& Theory, 39 (1), 125-150.

S. Ichsani and A. R. Suhardi. (2015). The Effect of Return on Equity (ROE) and Return on Investment (ROI) on Trading Volume. Procedia - Social and Behavioral Sciences, Vol. 211, 896-902.

W. Al-Ghanem and M. Hegazy. (2011). An Empirical Analysis of Audit Delays and Timeliness of Corporate Financial Reporting in Kuwait. Eurasian Business Review, Vol. 1, 73-90.

Z. Š. Grdić, M. K. Nižić and M. Mamula. (2017). Insolvency in the Republic of Croatia. Economic Research-Ekonomska Istraživanja, 30:1, 1693-1704. 